\title{
WESTERN CAPITALISM AND EASTERN EXOTICISM: ORIENTALISM IN EDWARD SAID'S PERSPECTIVES
}

\author{
Ronald Maraden Parlindungan Silalahi \\ Universitas Bunda Mulia \\ rsilalhi@bundamulia.ac.id
}

\begin{abstract}
Postmodernism fundamentally supersedes the ideas of modern ages that base their perspective on rationality and objectivity into postmodern thought that aimed at improving awareness of the reality in human life. It is aimed at improving social or cultural conditions or circumstances and to build the forms of awareness about realities that occur in human life in all spheres of life. This conception ultimately awakens Edward Said to a social phenomenon associated with the Western (colonialist) and Eastern (orientalist). Through his writing entitled Orientalism, Edward Said links Western responses and worldviews (Orient) which are always based on the nature of preconceived and stereotyped. In this paper, the author will firstly reveal the thoughts of postmodernism and then associate them with the concept of Orientalism. At the end of this paper, the authors will conduct case studies on two texts that are considered to reflect the issues of orientalism.
\end{abstract}

Keywords: postmodernism, orientalism, Edward Said

\begin{abstract}
ABSTRAK
Postmodernisme pada dasarnya menggantikan gagasan era modern yang mendasarkan perspektif pada rasionalitas dan objektivitas ke dalam pemikiran postmodern yang bertujuan untuk meningkatkan kesadaran akan realitas dalam kehidupan manusia. Hal ini bertujuan untuk memperbaiki kondisi atau keadaan sosial atau budaya dan untuk membangun bentuk kesadaran tentang realitas yang terjadi dalam kehidupan manusia di semua bidang kehidupan. Konsepsi ini pada akhirnya menyadarkan Edward Said akan sebuah fenomena sosial yang terkait dengan ideologi Barat (kolonialis) dan ideologi Timur (orientalis). Melalui tulisannya yang berjudul Orientalisme, Edward Said menghubungkan tanggapan Barat dan pandangan dunia (Orient) yang selalu didasarkan pada prasangka dan stereotip. Dalam tulisan ini, penulis pertama-tama akan mengungkapkan pemikiran postmodernisme dan kemudian mengaitkannya dengan konsep Orientalisme. Pada akhir makalah ini, penulis akan melakukan studi kasus pada dua teks yang dianggap merefleksikan isu orientalisme.
\end{abstract}

Kata Kunci: postmodernisme, orientalisme, Edward Said

\section{INTRODUCTION}

\section{Background of the Study}

The term 'postmodern' was firstly coined by Arnold Toynbee (1939) in his famous book, Study of History. Postmodernism fundamentally supersedes the ideas of modern ages that base their perspective on rationality and objectivity into postmodern thought that aimed at improving awareness of the real reality in human life. In the context of culture, postmodernism is always associated with the fusion between low and high cultural areas, performances and reality, universal and peripheral and every form of interpretation that emphasizes binary opposition conventionally exalted by philosophers in the previous era (Irvine, 2010). It is clear that modern post can be interpreted as a fusion in all fields. Postmodernism, however, does not reject a form of intensification which ultimately leads to the expansion of concepts in all fields to renew and revolution as a form of contradiction to every great narrative (meta narrative) form and to find contemporary forms or representations (Lindas, 2013).

In this paper, the author discusses about Edward Said, one of the famous postmodern figures with postcolonial theory and issues related to orientalism. At the end of this paper, the author will elaborate Said's thoughts in a case study to enlight the conceptual foundations underlying Edward Said's thoughts and views on Western hegemony toward the east through his idea of orientalism. 


\section{Objectives of the Study}

Based on the background above, the researcher is interested to investigate two types of texts which are considered to reflect the ideology of orientalism. This study aims at discovering the Western's views on orientalism in the comic strips "The Adventure of Tintin."

\section{LITERATURE REVIEW}

\section{Edward W. Said: A History Record}

Edward William Said was born in Jerusalem on November 1, 1935 and died on September 23, 2003 (Karim, n.d.). Said was born from a family with a different background. His mother, Hilda was a Nazareth-born Palestinian and his father, Wadie Said, was born in Jerusalem. Said started his formal education in GPS or Gezira Preparatory School (Prasetyo, 2009). After graduating from GPS, Said continued his education at CSAC (Cairo School for American Children). In 1951, Said left Cairo and continued his education at Princeton University on a literary review. In this place, Said developed himself and began writing a number of writings.

Said's life experience became a strong foundation that was reflected very clearly in his writings (Prasetyo, 2009). Conflict, injustice, oppression and western colonialism against the east he experienced during his stay in Jerusalem, Egypt, and while living in the United States became the trigger for writing his critical works related to colonialization and Western perspectives on the East (Prasetyo, 2009). Said realized there were a number of negative-indicated stereotypes communicated by colonizing countries against their colonies. This inequality is evident in literary works written by Western writers.

In his book Out of Place, Edward Sapir reveals personal confessions of his alienation to his own origins, the name he carries, his language, and his constantly mobile environment. It is evident that the bitter experience in Said's life became a whip for opposing the forms of western capitalism that developed in the scientific world (Prasetyo, 2009). As a people with a colonized Country background, Said often experienced humiliation, oppression, and tension during the war. The variety of identities within him seems to have made Said squeezed between the two Western (American and Protestant) and Eastern (Arab and Muslim) worlds causing various contradictions about who he really is ("Teori postkolonial Edward W. Said," 2015). However, it further helped him understand the living contradictions between Western and Eastern, Religion, colonialism, and independence.

From a number of published works, Issues related to the deprivation of the right of the Palestinian people by Israel became a very prominent issue. In the "the Question of Palestine" and "The Politics of Dispossession", Said (2012) criticized Yasser Arafat's leadership that allowed the Oslo Convention to be signed in 1993 because it would prevent the Palestinian refugees from returning to their place of origin.

As a writer, Said is known for his productivity (Callaghan, 2003). Most of the published books relate to Middle Eastern issues, such as Orientalism (1978), The Question of Palestine (1979), Covering Islam: How the Media and the Experts Determine How We See the Rest of the World (1981), The Politics of Dispossession: The Struggle for Palestinian Self-Determination, 1969-1994 (1994), and Peace and Its Discontents: Essays on Palestine in the Middle East Peace Process (1995). Said's other books are The World, the Text, and the Critic (1983), Nationalism, Colonialism, and Literature: Yeats and Decolonization (1988), Musical Elaborations (1991), and Culture and Imperialism (1993), and memoirs Out of Place (1999).

\section{Constructing Edward Said's Thoughts: Orientalism and Hegemonization}

In his book entitled Orientalism (1978), Edward Said describes his analysis of literary works of orientalist countries such as Britain, France and America, which are considered to be the cornerstone of other countries (Eastern Countries and Islam) ("Orientalism (book)," n.d.). In his presentation, Said began by presenting the history of the French Invasion to Egypt and the rise of turbulence in colonialism (Hamadi, 2014). The etymologically elevated "Orientalism" header comes from the word "orient" and "oriental" which is always associated with the nation and people of the East (Marandi, 2009). The East implies Asian 
countries that are considered as "sunrise" countries.

Orientalism, as adopted by Said in Orientalism, is associated with Western responses and views of the Orient (Alwee, n.d.). In Said's perspective, Western perceptions and perceptions of the Eastern Man are always based on the nature of preconceived. So it is very real if these thoughts are a form of stereotype. In contrast, low civilizations, primitive, and so on are some form of western negative perspectives on eastern exoticism that are intrinsically cultured and have been living for hundred years. The above depictions can be seen through the following illustration.

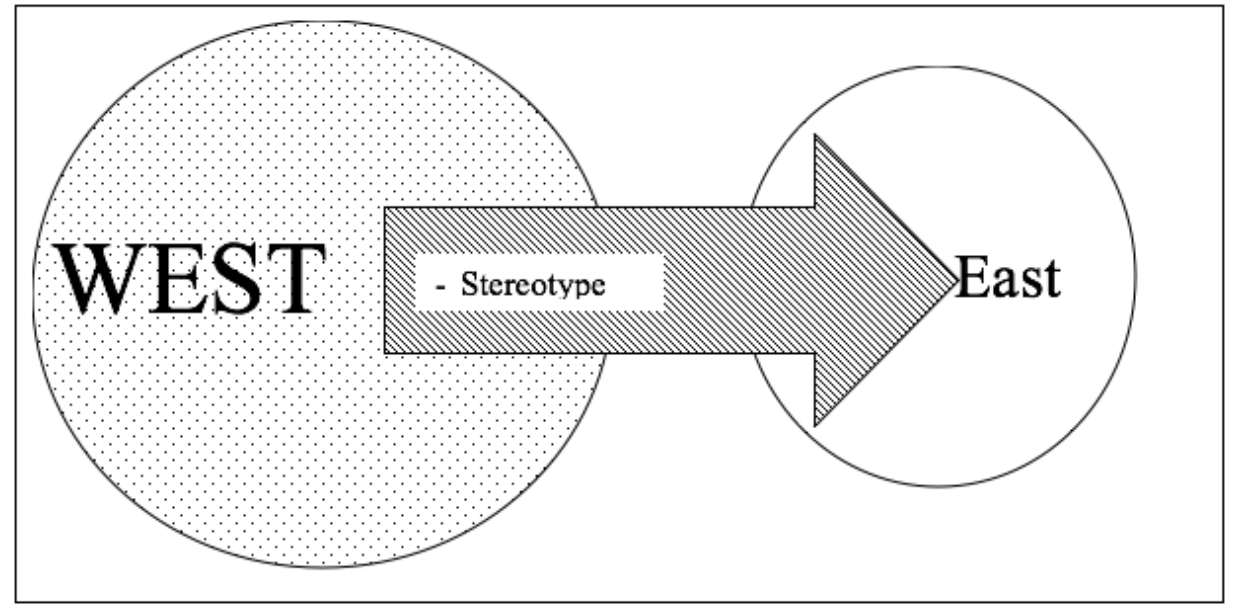

Figure 1. Orientalism

Figure 1 shows that the western world communicates preconceived messages and stereotypes. It is used to describe the eastern world. In the end, it builds and strengthens the power it possesses in the colonial era.

Alwee (n.d.) states that the West perceives that Orient has the following characteristics:

a) Eastern culture is always monolithic;

b) Eastern culture is static ('stagnant') and difficult and cannot even change;

c) Eastern cultures of low quality and simple and irrational;

d) Eastern culture is considered backward and primitive, but exotic and strange.

In Orientalism, Said (1978) revealed a study on history, literature, and art in European countries (Darry, 2013). Said stated that the works of the Europeans regard the Eastern nation as something different (the other) the way the easterners interpret and perceive themselves (Alwee, n.d.).

Orientalism is ultimately interpreted as an ideology that positions the west as the center in relation to the East (Said, 1978; Jones, Eliade, \& Adams, 2005). According to Said (1978), the development of the idea of orientalism in order to build a thought that has unconsciously legitimized the demands of countries called oriental. The Oriental not only refers to the Western world as a whole but also the things it contains, such as leaders, education, literature, literature, and even Western art. Indirectly dominated triggered the existence of economic and political control of the countries in colonialization.

Edward Said's argumentation base is based on the fact that it found about 60,000 books written by the West. Through its cultural hegemony towards the East, the West portrays the Near Orient with a negative and degrading perspective (Karim, n.d.). If we compare with the East (and include Islam) to study Western civilization and cultural heritage, we can see that the East tends not to touch the western world. This exposure implies Said's beliefs that regard orientalism as something always associated with three phenomena. First is Orientalist. Orientalists are the specific parties of people who come into contact with the east through the process of teaching, production of works, and research on the eastern world (Said, 1978; Jones, Eliade, \& Adams, 2005). These include anthropologists, sociologists, writers, researchers, historians, philologists, who have special knowledge and abilities of the western world and the phenomena associated with it. 
Secondly, Orientalism is a way of thinking and thinking that affirms a significant difference between the Orient and the Occident (Said, 1978; Jones, Eliade, \& Adams, 2005). In a broader view, Orientalism can be interpreted and viewed as a legitimated institution for dealing with the East (Said, 1978; Jones, Eliade, \& Adams, 2005). They provide a view of the eastern world, justifying the stereotype of the East that has not yet been tested.

\section{Orientalism in Global Context}

Understanding Orientalism cannot be seen in a narrow context. Fundamentally orientalism lives and remains for the duration of the colonial process. The imperialists build their strength by discrediting the colonialized. This has happened all the time and history of human life.

Alwee (n.d.) reported that the Orientalists studied and looked at the East with some trends or ideas that can be broadly divided as follows:

a) Looked at the 'ahistorical' issue. In this case, the changes that occur in the environment and culture from time to time are not a matter of concern. Western thinkers are always prejudiced that the orientation remains the same from before, now, and to the future. This is certainly contrary to post-modern thinking that rejects permanent and static forms.

b) The works of colonial era are rich in negative stereotypes and prejudices to the East. For example, natural disasters occurring in Asia that are always associated with Islamic beliefs; or even statements that undermine the physical nature of the small, yellow-skinned Chinese society that is always associated with the prisoners and the weak.

c) The reductionist explanation which links certain conditions with other scientifically illogical factors. Factors that inhibit the development of society that is always associated religion and the attributes attached to the culture. For example, the economic downturn in Asia is often associated with the character of the eastern society.

d) Focuses on analyzing transitory texts and not appealing to the context (time, place, and history) that fundamentally influence the interpretation behind the text. In essence changing constantly, events that ever happened (history) are not completely the basis for a thorough understanding of current events

e) It does not emphasize the social approach in understanding the phenomena occurring in eastern society. Western thinkers emphasize the search for data that is compatible with the concepts of hegemony to be conveyed in the text and heed the proper method approach that should be used.

f) Not lifting the phenomenon of culture holistically. Cultures assessed as having high value tend not to be raised or delivered. This confirms the existence of efforts to strengthen Western capitalism and undermine the noble values of the East.

The issue of Orientalism basically has its place in humanities and social studies. To understand the phenomena associated with orientalism, a researcher must understand the underlying context of the issue. For example, to dissect Orientalism in China it is necessary to conduct historical tracing related to the occupation. In this case, the issue of orientalism would certainly be associated with British colonization and its occupation. The resulting literature will certainly be the basis for building the analysis.

In his presentation, Said (1978) asserted a very strong relationship between the East and the Islam. Asia is regarded as a center for the spread of Islam. In a number of Western literature; This hatred can be clearly seen from orientalist works that describe and associate the teachings of Islam with negative mystical things associated (Prasetyo, 2009). Even in other literature can be seen a number of orientalists who describe the Prophet Muhammad, Islam, and the Qur'an negatively.

In his analysis, Said presents a critical analysis with a new way to analyze the history and social phenomena that have occurred. Based on the method of deconstruction, Said is able to show and explain the ways in which some discourses, values, and knowledge reconstruct facts through an independent approach (Susanto, 2008). The incorporation of methods used in literary studies by focusing on critical 
analytical methods confirms the assertiveness and purpose of the writings that are striving for humanitarian endeavors.

\section{RESEARCH METHOD}

In order to understand orientalism in depth, the author will try to apply the concepts and basics associated with orientalism to analyze these issues in two published texts and in colonial and post colonial times. The two texts that were raised were comic "The adventure of Tintin" written by Herge.

\section{FINDINGS AND DISCUSSION}

In this section, the author will apply Edward Said's thoughts to analyze a famous comic book entitled "The Adventure of Tintin" written by a famous Belgian comic artist named Georges Prosper Remi or better known as Herge. As for the comics that will be of concern in this case is the comic series "The Blue Lotus" written and published in 1934. Figure 2 and 3 are parts of the comic that explicitly shows the orientalism imagery that is reflected in this comic.

In order to understand the issue of orientalism as reflected in the text above, it is necessary to understand the context behind this paper holistically. From this comic came the character of Tintin. Tintin is a young reporter and adventurer who is always accompanied by a loyal dog type fox terrier named snowy. The first strip comic of the series "The Adventure of Tintin" was "The Land of Soviet" on January 10, 1929 until May 8, 1930.

The series "The Blue Lotus" was written in August 1934 and colored 1945. Simply put, this comic tells Tintin a journalist's journey to China after receiving news that one gets word about the enemy who wants to avenge Tintin.

In the comic strips in Figure 2, it can be seen that a fakir does the walking and dancing on a pile of nails. The reaction given by Tintin in the above comic through the "He's Quite Extraordinary" speech shows Tintin's admiration for what the Fakir did. However, the reaction also shows a rejection of irrational action to be performed.

In the context of Fakir culture, the act of putting out the body shows acceptance and concession to God. Fakir itself is a form of self-purification so it is very reasonable to be interpreted as a form of high value culture. Herge in the above comics shows how irrational the Indian culture is. It is also very visible on the third line, the needy is asked to sit in a comfortable chair to be able to convey his prophecy to Tintin. Comfort provided through the sofa just means suffering for the poor. Therefore, the fakir asks to sit in the pile of nails because they are not accustomed to living in comfort.

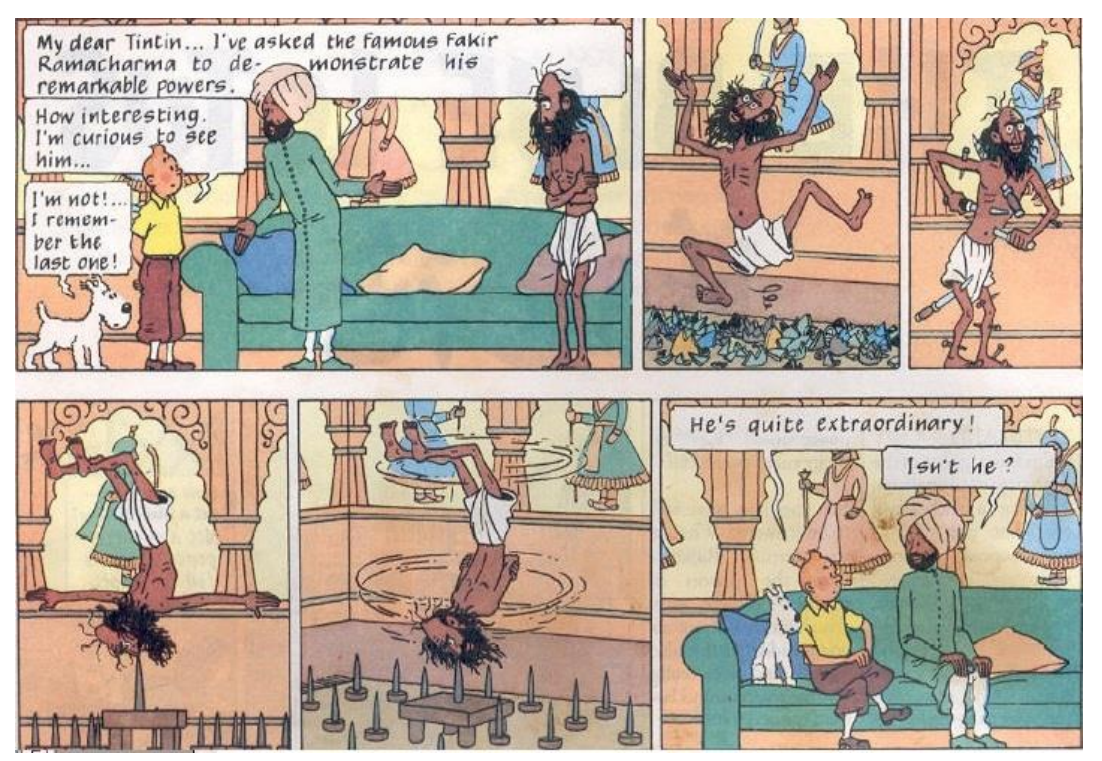

Figure 2. $1^{\text {st }}$ Comic Strips of "The Adventure of Tintin" in "The Blue Lotus" (1934) 

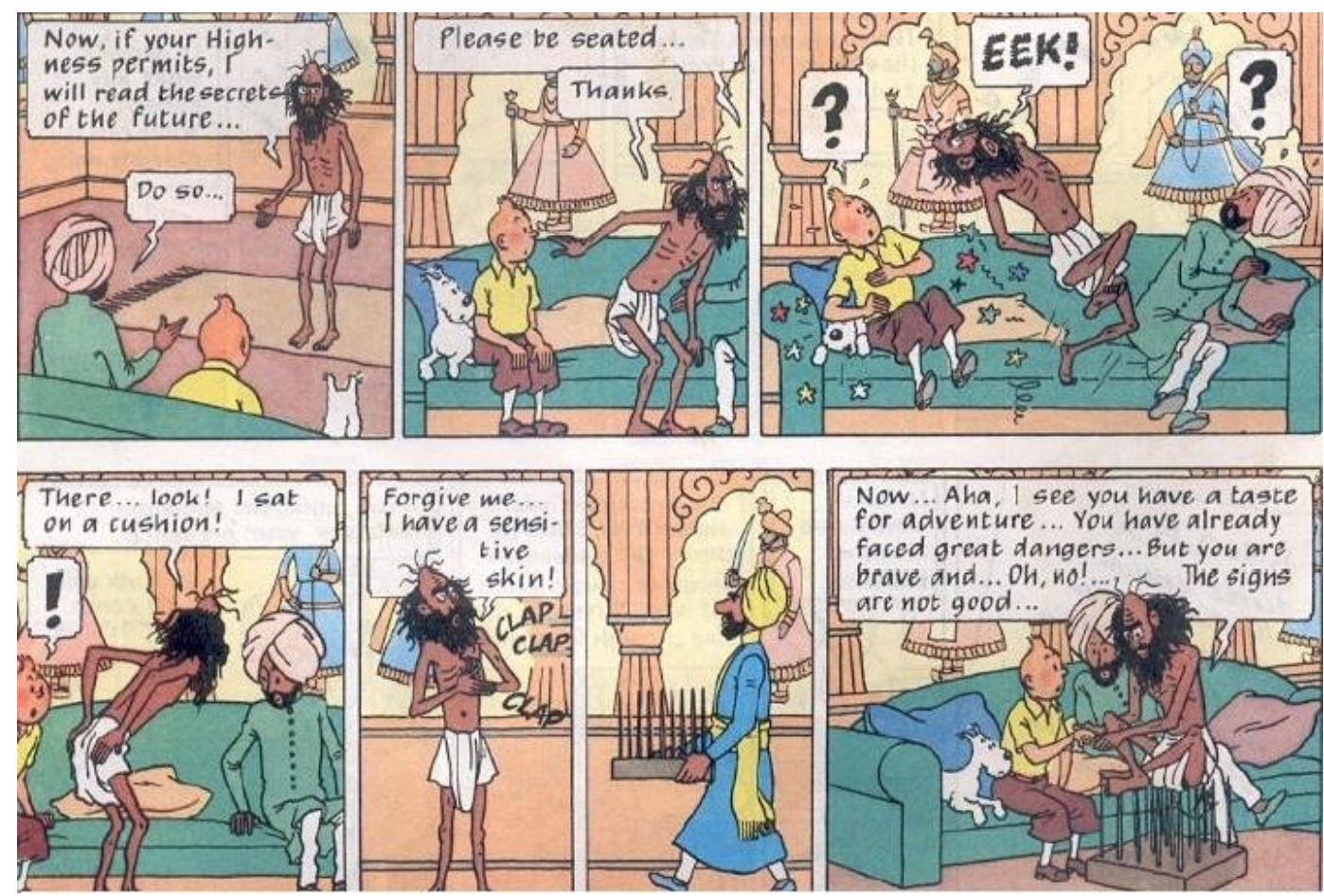

Figure 3. $2^{\text {nd }}$ Comic Strips of "The Adventure of Tintin" in "The Blue Lotus" (1934)

Discrimination against orientals is clearly visible in every part of this comic. In some columns Herge can clearly see the Western view of the East.

In Figure 4, it can be seen a rickshaw dancer who is described as similar to the Chinese (marked by a thin eye shape and the "China-man" clothing) that hit a Westerner who was symbolized with a jacket, a stick, a hat, and a newspaper.

Responding to the accidents, people who have a symbol of the West provide a response that shows the western view of the Chinese people. In this case, the Chinese are viewed as being dirty and looking inappropriate.

Herge in this comic also affirms the superiority of western society if compared with the community. The western society is considered to have a higher culture than the eastern counterparts. This is clearly recorded in Figure 5.
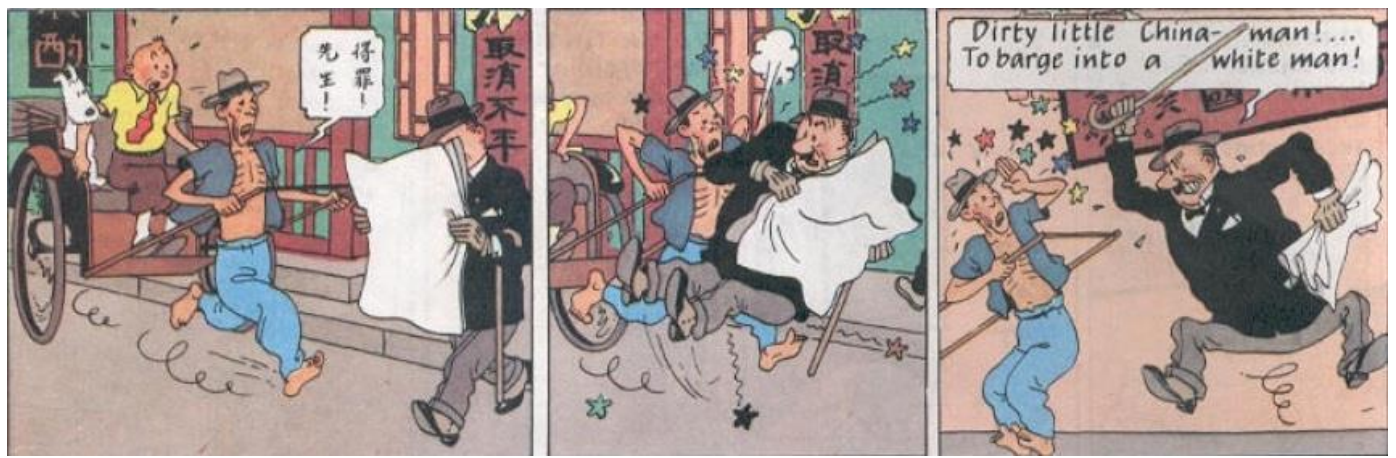

Figure 4. $1^{\text {st }}$ Comic Strips of "The Adventure of Tintin" 


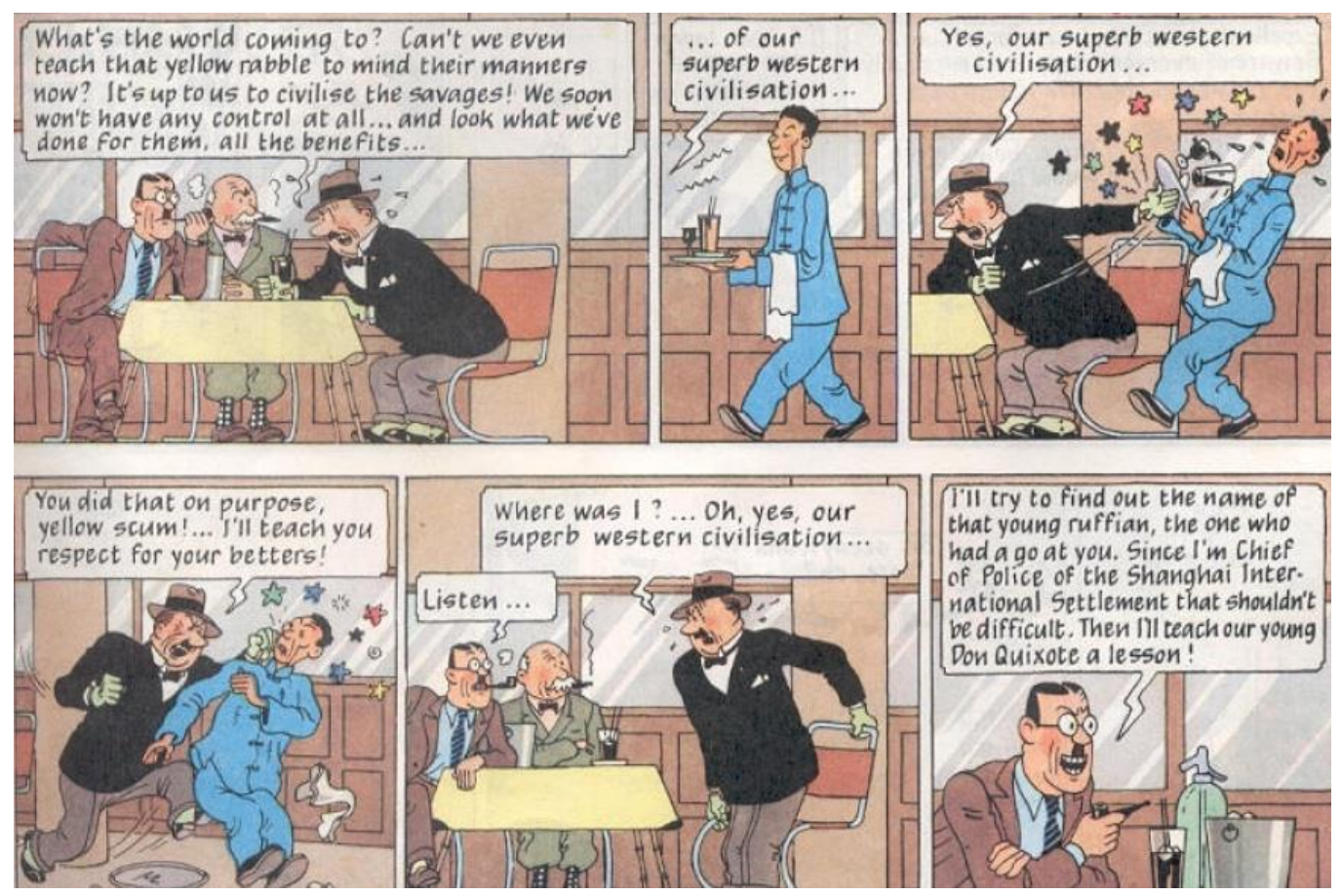

Figure 5. $2^{\text {nd }}$ Comic Strips of "The Adventure of Tintin"

The quotation above illustrates the western way of thinking of the eastern people. The rabble word 'common man' (on the first line), 'primitive' savages (on the first line), and scum 'mud or referring to a lowly man' (on the second line) indicate that westerners view the eastern man as Primitive. This is communicated to western participants so as to affirm the agreement between each 'western' participant for the statement.

In a conversation between Western participants, the statement "Our Superb Western Civilization" can be seen. This shows the recognition of Western superiority that is considered civilized to the Eastern culture. In essence culture in a more humble view cannot be superior to other cultures. Each culture has its own uniqueness and uniqueness that can not be compared or assessed with a single cultural perspective.

\section{CONCLUSION}

Postmodern thought provides a picture of reality that cannot be seen directly. Reality cannot be seen the process of deep analysis of a text. In the context of his presentation, ideology is in line with imperialism. The power of the text may affect communication. Therefore, the meaning found in the text cannot be seen as an absolute reality.
Postmodern thoughts are clearly reflected in Edward Said's writings. The truth that has been so far conveyed through classical literatures is built on untested untruth. Power allows for a message bending. Colonialism, imperialism, domination reinforce the mastery of texts within society. This mastery ultimately does not only lead to the wrong communication process. In a higher level the mastery of this text leads to a negative perspective, sentiment, and hatred.

According to Said, Orientalism refers to an unexamined point of view. The western world controlled by colonialists strengthens its power by using texts. In addition to mastering the economy and politically the orientalists build bad sentiments over their colonies. Primitive, different, and exotic are the number of labels assigned to the eastern countries. This seems to imply that the colonial state is not as human as the western world. This negative sentiment not only leads to the perspective of a particular culture. At a more complex level the negative sentiment builds negative stereotypes on the cultures and religions owned by the colonized. This untested Orientalist thought is reinforced by orientalists who master the academic sphere. Throughout the history of colonialism the western literatures are filled with unfounded stereotypes. 


\section{REFERENCES}

Alwee, A. I. (n.d.). Malay studies and orientalism. Retrieved from http://www.thereadinggroup.sg/Article s/Malay\%20Studies\%20\&\%20Oriental ism.pdf

Callaghan, C. (2003). Selected Bibliography of Work about and of Edward Said's Texts. CLCWeb: Comparative Literature and Culture, 5(4), 7.

Darry, M. (2013, May 21). Orientalisme. Retrieved from http:// mohammaddarry-fisip12.web.

unair.ac.id/artikel detail-79327Ide $\% 20 \% 20$ Ide $\% 20$ Politik\%20Alternat if-Orientalisme.html

Hamadi, L. (2014). Edward Said: The Postcolonial Theory and the Literature of Decolonization. European Scientific Journal, ESJ, 10(10).

Irvine, M. (2010). 'The Postmodern,' 'Postmodernism,' 'Postmo dernity': Approaches to PoMo. Georgetown. edu. Website, 11 .

Jones, L., Eliade, M., \& Adams, C. J. (2005). Encyclopedia of religion. Detroit: Macmillan Reference

Karim, A. R. (n.d.). Edward W. Said. Retrieved from http://www. academia.edu/21798822/EDWARD W . SAID.

Lindas, J. (2013). Engaging with Postmodernism: An Examination of Literature and the Canon.

Marandi, S. M., \& Pirnajmuddin, H. (2009). Constructing an Axis of Evil: Iranian Memoirs in the 'Land of the Free'. The American Journal of Islamic Social Sciences, 26(2), 23-47.

Orientalism (book). (n.d.). Retrieved from https://www.revolvy.com/ main/index.php?s=Orientalism\%20(bo ok)\&item_type=topic

Prasetyo. (2009, August 25). Edward Said: Menembus barat dan timur. Retrieved from https:// tokohbangsa.wordpress.com/2009/08/2 5/edward-said-menembus-barat-dantimur/

Remi, G. P. (1983). The blue lotus. London: Mathuen Publishing.

Said, E. W. (1978). Orientalism. New York, NY: Pantheon Books.

Said, E. W. (1979). The question of Palestine. New York, NY: Times Books.
Said, E. W. (1981). Covering Islam: How the media and the experts determine how we see the rest of the world. New York, NY: Pantheon Books.

Said, E. W. (1983). The world, the text, and the critic. Cambridge, MA: Harvard University Press.

Said, E. W. (1988). Nationalism, colonialism, and literature: Yeats and decolonization. Derry: Field Day.

Said, E. W. (1991) Musical elaborations. New York, NY: Columbia University Press.

Said, E. W. (1993) Culture and imperialism. New York, NY: Knopf/Random House.

Said, E. W. (1994). The politics of dispossession: The struggle for Palestinian self-determination, 19691994. New York, NY: Pantheon Books.

Said, E. W. (1995). Peace and its discontents: Essays on Palestine in the Middle East peace process. New York, NY: Vintage Books.

Said, E. W. (1999). Out of place: A Memoir. New York, NY: Knopf.

Said, E. W., Eagleton T., \& Jameson, F. (1990). Nationalism, colonialism, and literature. Minneapolis: U of Minnesota $\mathrm{P}$

Siegel, K. (n.d.). Introduction to Modern Literary Theory. Retrieved from http://www.kristisiegel.com/theory.htm

Susanto, H. (2008, May 8). Membongkar Hegemoni Wacana Sosiologi Barat. Retrieved from http://www.averroes.or.id/membongkar -hegemoni-wacana-sosiologibarat.html

Teori postkolonial Edward W. Said. (2015, January 5). Retrieved from https://linguag3.wordpress. com/?s=edward + said

Toynbee, A. (1939). A study of history (5th Volume). London: Oxford University Press. 